ORIGINAL ARTICLE

\title{
Becoming a nurse: "it's just who I am"
}

\section{Flaming}

See end of article for authors' affiliations

.....................

Correspondence to:

Don Flaming, RN, PhD

(Nursing), School of

Nursing, Medicine Hat

College, 299 College $\mathrm{Dr}$

$\mathrm{SE}$, Medicine Hat, Alberta,

Canada, TIA 2E6;

dflaming@mhc.ab.ca

Received

11 November 2005

Accepted for publication

16 March 2005
In any research study, researchers situate themselves, either explicitly or implicitly, within a variety of frameworks when studying phenomena. From a research perspective, the study will be more robust if these frameworks and the accompanying assumptions are compatible with each other; otherwise, the project may lack coherence. Ricoeur offers a methodological perspective-that is, an interpretive theory as reflected in mimesis, which is congruent with his ontological theory of self identity (ipse- and idem-identity). To illustrate Ricoeur's frameworks when researching the self identities, I use examples from a research study in which I asked senior nursing students to explore their experience of becoming a nurse. I do not intend for this article to be a comprehensive research report, but I present it as an exemplar of how Ricoeur's ideas can guide other researchers studying self identity. I labelled my study a narrative research project and assumed that becoming a nurse means developing a self identity as a nurse. While self identity is often framed in psychological terms, Ricoeur uses a philosophical perspective when exploring this concept. I conclude the paper by suggesting (a) that Ricoeur can guide any project in which researchers ask participants to describe "becoming" a person with illness, sickness or disease, and (b) that educators of healthcare professional students can improve the educative experience by purposefully considering how a student's ontological self affects that student's practice.
A s a nurse educator, I am always interested in exploring a nursing student's experience of becoming a nurse. Other people agree and have used sociological concepts-for example, professional socialisation and role socialisation-to explore nursing students quantitatively. ${ }^{1-6}$ Researchers approach the topic qualitatively too, using phenomenology, ${ }^{7-10}$ grounded theory, ${ }^{11}$ and ethnography. ${ }^{12}$ These authors all provide insights into the nursing student experience, but theirs is not an explicitly ontological orientation. In a research project in which I asked student nurses to explore with me their experience of becoming a nurse, I was guided by an ontological theory, not a sociological or psychological one. I am not an expert in ontology, but I believe that philosophical insights into experiences are valuable for nursing practice and nursing education, just as I value insights from sociology or psychology. The purpose of this paper is not to present a comprehensive report describing a research study, but by referring to my study, I will argue that Ricoeur's narrative theory as reflected in mimesis and his ontological theory, when used together, is a fecund approach for researching constructions of self identity.

Because my primary purpose is not to provide a comprehensive description of a research report, I do not give a full account of my research project, but I will provide a brief description of the context. After receiving approval from an ethics review board, I obtained consent from 10 senior level female nursing students who all had a previous degree in another non-nursing discipline. I would not necessarily have excluded men from the sample, but none volunteered. I interviewed all volunteers in this convenience sample at least once and interviewed four of the more reflective and articulate students two more times. I interviewed students over three academic semesters and a professional transcriptionist transcribed these 18 interviews. I have not included excerpts from all 10 women in this paper, even though all participants contributed to my understanding, because my primary purpose is to highlight the appropriateness of Ricoeur's thought in research, rather than presenting a typical research report.
As a nurse researcher, I am most familiar with other nurse researchers who have transposed Ricoeur's philosophical thinking to the research process. Nurses have studied a variety of experiences, including suicidal psychiatric patients ${ }^{13}$; the experience of caring for a person acting in a disturbing manner ${ }^{14}$; the meaning of fatigue in women with fibromyalgia and healthy women ${ }^{15}$; the suffering experienced when being cared for ${ }^{16}$; understanding a woman's experience of an acute myocardial infarction ${ }^{17}$; patients' experience of understanding stroke ${ }^{18}$; the experience of being a hospice nurse ${ }^{19}$; living with symptoms related to Parkinson's disease, ${ }^{20}$ and exploring registered nurses' meaning of identity. ${ }^{21}$ All these researchers reference Ricoeur' ${ }^{22}$ Interpretation Theory: Discourse and the Surplus of Meaning as the main source for their understanding of interpretation. Based on Ricoeur's book, these researchers incorporate a three stage process in their interpretive process and move from understanding (a naïve grasping of the story) to explanation (structural analysis of the text) to comprehension (referred to by the authors as a more sophisticated mode of understanding). I suggest that this three step approach, while useful, is insufficient to grasp Ricoeur's understanding of interpretation. Some researchers do reference Ricoeur's $\mathrm{s}^{23}$ collection of essays called From Text to Action when describing their interpretive approach, but an exploration of his methodology - that is, mimesis, not just the method he describes, helps me better understand the interpretive experience. None of the above researchers do reference Time and Narrative, ${ }^{24}$ the book in which Ricoeur discusses mimesis, the cornerstone of his interpretive theory, though as the title suggests, Ricoeur believed that temporality is key to understanding how people construct narratives of the self.

By combining Ricoeur's well known narrative theory as a research methodology and his ontological theory as a guiding framework for research, researchers are presented with a fecund combination that can result in a decidedly philosophical exploration-that is, ontological, of the experience under consideration, rather than-for example, a sociological or psychological understanding. I was informed by a Ricoeurean interpretive research methodology and 
Ricoeurean ontology when studying nursing students' developing self identities as nurses. Some people might assume that "self identity" is a psychological concept and in many contexts it is, but Ricoeur uses the word philosophically, that is, from an ontological perspective when exploring how people understand themselves as a particular human being. Ricoeur states that his book, Oneself as Another, ${ }^{25}$ is a comprehensive exploration of his ontology and, to my knowledge, Fredriksson and Eriksson ${ }^{26}$ are the only other nurse researchers who-in their study focusing on the ethical foundations for a caring conversation-reference this book.

When I asked a participant in my study, Kate, why nursing suited her, she said: "It's just who I am". From Kate's perspective, the practice called "nursing" fits her self identity-that is, her ontology, just as nursing fits Anne, another participant. Anne believes that the fit between her self and nursing practice is "even becoming stronger. When I was applying for the programme, no one would have told me it's a calling...but now that I'm in it, it does." Being called to the nursing profession is more than just having the necessary educational credentials or having the necessary skills, it is rather a feeling of fulfilment at a deeply personal level; being called means being fulfilled ontologically. No conflict exists between what Anne does in her nursing practice and what her self, developed over time, does as a human being. She says: "I don't have to act the role of nurse...It's too difficult to be different [than being myself]...It just feels right. That was a sign to me." Anne would deceive herself and others if she acted differently when nursing than when she is not nursing. Being a different person in one situation to the next would not only be difficult, but would also be quite wrong because she would be lying to herself.

\section{RICOEUR'S UNDERSTANDING OF NARRATIVE AND MIMESIS}

For Ricoeur, a person's personal narrative is a construction that helps that person make sense of who she or he is as a human being. This construction is a temporal one because people include past, present, and future action in these narratives. Actions are meaningful because they reflect who that person is as a particular human being. When fully explored, these actions are actually public expressions of inward motivations. Action reflects a person's ontology and, "To identify an agent and to recognize this agent's motives are complementary operations" (Ricoeur, ${ }^{24}$ p 55). By exploring motivations for action, not from a psychological perspective, but from an ontological one, we learn who that person is as a particular human being. Valdés characterises Ricoeur's interpretive process as "the return to the world of action as the basis for all meaning; this is the cornerstone of Ricoeur's theory of interpretation" ${ }^{27}$ Ricoeur, a philosopher, never describes a research method, but his methodology is especially appropriate for my study because when asked about becoming a nurse, participants reflected on their actions with other people. By doing this, students made sense of, or constructed, who they are and who they want to be as a nurse.

Ricoeur believes that temporality is part of a person's narrative construction. Self understanding cannot occur by considering our personal experiences chronologically; rather, Ricoeur assumes that certain experiences in a person's life are more important than other experiences when constructing a comprehensible self. He states that the self is an empty place if, indeed, each experience in our lives is given equal importance. Our self is vastly richer if time is considered to be "a gathering moment where expectation, memory and present experience coincide" ${ }^{28}$ From a Ricoeurean perspective, participants in my study offer a richer understanding of their selves becoming nurses when, through the narrative, they gather together their past, present, and future experiences. These nursing students remember, and anticipate, important events that shape who they are as nurses or who they will become as nurses. Their memory of past experiences, their experience of the present, and their imagined future experiences coalesce into a constructed self identity-a particular human being. Participants state categorically that the experiences they consider when thinking about becoming a nurse are not limited to nursing education, but include many life experiences which play an important role in their construction of self.

Ricoeur's unique contribution to interpretive theory is his understanding of mimesis. ${ }^{29}$ This concept, from the ancient Greeks and the classical theory of $\operatorname{art}^{30}{ }^{30}$ describes how people imitate past experiences so that others can experience the event. This imitation often occurs through artistic means, including narratives, and unlike narrativists before him, Ricoeur describes three subsets of mimesis. (Ricoeur, ${ }^{24} \mathrm{pp}$ 52ff] He does not suggest a linear process, but by separating mimesis into three parts, he can clarify the holistic nature of the interpretive process. The subsets are mimesis (prefigura- $^{-}$ tion or prefigured time), mimesis 2 (configuration or configured time), and mimesis 3 (refiguration or refigured time). They are "a fundamentally circular and reflexive nature of understanding". ${ }^{31}$

\section{Mimesis $_{1}$}

Mimesis $_{1}$ refers to preunderstandings of the world that motivate a person to act. For Ricoeur, mimesis ${ }_{1}$ "applies to our existing commonsense view of the world in which we have gained experience of organizing events in a particular way in making sense of the world". ${ }^{32}$ The phrase "common sense" implies that people act on the basis of their understanding of shared assumptions about the world. Some assumptions are explicit—for example, linguistic rules shared by a group so that communication can occur-but some (or perhaps many) prefigurations are powerful, yet remain implicit and even inarticulable. Mimesis ${ }_{1}$ is "prefigured time" because many of our assumptions are not consciously figured into narratives of the self. Exploring these hidden assumptions can provide ontological insights into motivations to act as a particular human being.

Mimesis $_{1}$ is so important in the interpretive circle that Ricoeur states: "The most fundamental condition of the hermeneutic circle lies in the structure of preunderstanding which relates all explication to the understanding which precedes and supports $\mathrm{it}^{\prime \prime} .^{33}$ For researchers, exploring preunderstandings give glimpses into the motivations behind a particular person's actions. While Britzman does not use the word mimesis in her study exploring the experience of students studying to be teachers, she states that student teachers "bring to teacher education their educational biography and some well worn and commonsensical images of the teacher's work". ${ }^{34}$ These biographies and "commonsensical" images are, I think, examples of the prefigurations $\left(\right.$ mimesi $\left._{1}\right)$ that Ricoeur discusses.

\section{Mimesis,}

Ricoeur refers to mimesis 2 as emplotment or the "configuring time" that, using an analogy of place, lies between the prefigured time reflected in mimesis ${ }_{1}$ and a person's inter-

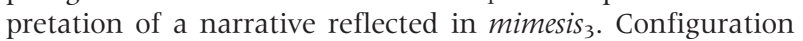
"opens the kingdom of as if [italics in the original]" (Ricoeur, ${ }^{24} \mathrm{p} \mathrm{64)}$ ). As if does not mean that a person's narrative is fiction, in the sense of having no basis in real events; rather, when people construct narratives, they really believe that events happened just as they remembered them. Their narratives are fiction in the sense that a person's prefigurations, both implicit and explicit, taint the narratives. 
Narratives of the present are never innocent; they are always guilty of being influenced by the past and future. People impose an order on their experiences, or construct their experience, as they try to imitate their actual life experiences in memories for themselves and for others.

Using an aural metaphor, Ricoeur ${ }^{35}$ states that an isolated experience in a person's life is mute by itself and is made "eloquent" only when that experience is placed in a meaningful relationship with other events in life through narration. Only through this emplotment does time become configured human time as an expression of self identity, not simply as events occurring in a chronological order. I assume that participants' stories about becoming a nurse are not exact reproductions of their life events, but that a particular participant, shaped by her own prefigurations, uses a particular construction to make her experience comprehensible.

\section{Mimesis $_{3}$}

Mimesis $_{3}$ is refigured time and refers to "the time of action" (Ricoeur, ${ }^{24} \mathrm{p}$ 70) when the text meets, and inevitably influences, the reader. The text refigures the reader's life because, Ricoeur assumes, reading a text always has an impact upon the reader. In fact, for Ricoeur, the entire interpretive process (mimesis) is worthwhile only because narratives produce a reader to act. Ricoeur states that: "At the end of our investigation, it seems that reading is the concrete act in which the destiny of the text is fulfilled" (Ricoeur, ${ }^{24} \mathrm{p}$ 124). In interpretive research, the "concrete act" happens when the researcher reads the transcribed interviews. The researcher realises that the mimetic arc (or what some writers refer to as the mimetic circle) is complete in mimesis secause $_{3}$ a researcher's interpretation of participants' narratives is grounded in that researcher's own prefigurations (mimesis ${ }_{1}$ ). The relationship between mimesis ${ }_{1}$ and mimesis $s_{3}$ is so close that when we, as researchers, interpret our participants' narratives, we are also interpreting our own self. The interpreter becomes the interpreted as our own prefigurations shape our interpretation of someone else's narrative. When talking or writing about their research, interpretive researchers construct their own emplotments of participants' emplotments. When engaging in this construction, researchers must consider how their own prefigurations affect their decisions. This personal vigilance should not paralyse a researcher, but should remind us that no one "real" construction of the self exists. While similarities in researchers' constructions may very well exist if several people analyse the same data, researchers' selves, who are different from each other, will inevitably construct different interpretations of participants' selves. Through engagement in this study-for example, I found important prefigurations that included memories of my mother as a nurse, of experiences of my own nursing education, and of the curricular theory that I read.

Like any text, participants' words, once spoken, have a "semantic autonomy" (Ricoeur, ${ }^{22}$ p 30) allowing me, or forcing me as a researcher reading transcripts to interpret them. Because a text is distanced from the original speaker (nursing student)-an "exteriorization of discourse" (Ricoeur, ${ }^{22}$ p 43) - I have the opportunity to think about the implicit and explicit meanings of participants' narratives. As a researcher, I want to always privilege participants' narratives, but reading their texts is to "conjoin a new discourse [mine] to the discourse of the text [participants' words];" interpretation is "the concrete outcome of conjunction and renewal" (Ricoeur, ${ }^{23}$ p 118). Even if I remain acutely aware of my own assumptions and try to limit their effect on my decisions, my interpretation of participants' stories is inevitably influenced by my own discourse that joins the discourse of participants. I construct my own meanings of the meanings that participants have constructed. Through this process, "the text's career escapes the finite horizon lived by its author. What the text says now matters more than what the author meant to say" (Ricoeur, ${ }^{22}$ p 30 ) because the way I interpret the text motivates me to think and act in a certain way, even if that was not the author's intent.

This distanciation is an integral part of Ricoeur's theory because "each text is free to enter into relation with other texts" (Ricoeur, ${ }^{33}$ p 149). The text "no longer coincides with what the author wanted to say, verbal significance and mental significance have distinct destinies" ${ }^{36}$ Not only is the text distant from the author, but the text is also distant from the original situation and audience, thus allowing foror necessitating - even more interpretive freedom. A reader of any text, and that includes researchers who read transcripts of participants' interviews, reconfigure these texts to meet their own configurative needs. Once written, a text becomes autonomous, but, as I said earlier, researchers cannot simply put words into the mouths of participants to meet the researchers' needs. When researchers write their interpretation of participants' experiences, the written work is nestled within a constant tension between a participant's constructed meanings and the researcher's own constructions of those constructed meanings. An individual researcher's written work about a phenomenon reflects the way that the researcher chooses to re-present participants' experiences.

Tantillo describes this important characteristic of narrative work by stating that interpreters "read the text semantically as a work of meaning that is disconnected from the [original] author's subjective, mental intention". ${ }^{37}$ Usher, referring to interpretive and hermeneutic research, describes a "double hermeneutic...because both the subject (the researcher) and the object (other people) of research have the same characteristic of being interpreters or sense seekers". ${ }^{38}$ Participants in my study interpret, or make sense of, their experience as if their experience were shaping their becoming a nurse. My own prefigurations bias me as I interpret or make sense of their interpretations as if my interpretations make sense to me. You, the reader of my interpretations of participants' interpretation, are even further removed from the participants' narratives because, just as I reconfigure participants' texts when writing this article, you reconfigure my words as if they make sense to you.

\section{RICOEUR'S ONTOLOGY OR SELF IDENTITY}

Ricoeur's ontological theory of personal identity fits well with his narrative theory. In Oneself as Another, he specifically explores how people develop a self identity-for example, we all have names that provide some stability for our self identity. I am Don ever since I was born and I will continue to be Don until I die and even thereafter in people's memory. During my life, however, I have changed and will continue to change physically, mentally, emotionally, and spiritually. I am a very different individual now from when I was born, yet I am still Don. Relating this to my research study, participants enter nursing education with a self identity, but their experience working with patients, with other students, with other nurses, and with other healthcare professionals, somehow changes who they are or changes their self identity. Ricoeur's work helps me understand why participants say, on the one hand, that nursing education does not change them, yet also say that nursing practice does change them.

Ricoeur addresses this philosophical impasse regarding continuity of identity and change-is a ship that has all of its parts replaced over time the same ship now as when it first sailed? After an organ transplant, is the recipient the same 
person?-by distinguishing between idem-identity and ipseidentity. The former type of identity is the stable, unchanging sense of identity required for a person to feel grounded as a particular human being. If, however, a person is too grounded or too sedimented in the past, then that person cannot deal philosophically with the changes that a self inevitably experiences. An understanding of identity as ipseidentity, on the other hand, allows people to easily accept that stability and change are not mutually exclusive. A person's self identity as selfhood (ipse-identity) allows for change without the threat of that person becoming completely unidentifiable. Using a metaphor of place, and using classic examples from philosophy, Ricoeur suggests that an individual's narrative of self sits somewhere between the extreme of (a) the Cartesian cogito that traditionally reflects a static, immutable, exalted, and cognitively objective self ("I think, therefore, I $\mathrm{am}^{\prime \prime}$ ), and (b) a self that is completely shattered or dispersed, as Nietzsche suggests when he writes, "God is dead". In a philosophical way, Ricoeur promotes the idea that a healthy self identity happens when someone constructs a self based on a foundation that does not change so much that all former identity is lost, all the while being aware that a self does change somewhat so that all experiences can be incorporated into a coherent self.

Dunne thinks that Ricoeur advocates a self that is best explored through narratives and goes "beyond sovereignty [cogito] and deconstruction [Nietzsche]". ${ }^{39}$ By interpreting an individual's narrative, we can explore who someone is (or is becoming). Because a person needs to have some grounding - that is, their idem-identity, a self is not, as a Nietzschean might say, merely a "linguistic or rhetorical flourish" ${ }^{40}$ Diane Fuss, ${ }^{41}$ a feminist thinker, agrees that when we think about our identity, we cannot delete all notions of self (although she believes that we do need to problematise them), lest we become an undifferentiated mass. To deconstruct identity, as she advocates, is not the same as disavowing identity, and I think this is Ricoeur's point, too. The "nominal essence" or "strategic essentialism" described by Fuss reflects the fact that we have some stability, even as we also experience change.

Relating the distinction between idem and ipse-identity to nursing students becoming nurses, students reflect the Cartesian idem-identity when they deny that nursing education changes them in any way. Yet, they also describe changes to their self, not just increased knowledge, but at the level of being an excellent nurse. Jill-for example, talks about changing a core understanding of social rules. Early in her nursing education, as part of the morning routine, a nurse asked her to check a patient's vital signs and Jill had to become someone different from who she usually was:

\section{Sometimes you ignore your social conscious. This one time} I was supposed to be doing a vitals check. The patient was sleeping. I came back out... In normal life, someone is sleeping, I am not going to go wake them up and piss them off!

I can relate to Jill because I clearly remember the first time I had to take the morning vital signs. Because I, too, was following the social rule that sleeping people are not to be disturbed (a prefiguration or mimesi S $_{1}$ ), I stood in the hallway by the closed door for several minutes, unsure of what do to. I finally entered the room timidly, but I then wondered whether I should open the blinds, or whether to turn the lights on, or attempt to take vital signs in the very dim lighting. Both Jill and I had to change our prefigurations and change our assumptions about relating with other human beings.

\section{A TEMPORAL UNDERSTANDING OF A PARTICIPANT'S PERSONAL ONTOLOGY}

Ricoeur's thinking helped me frame participants' constructions of self as being temporal understandings because their past life experiences and their anticipated experiences as nurses strongly influence their present understanding of becoming a nurse. Nursing education, participants say, does not alter their basic sense of self, and never will, but experiences with patients mean that they express themselves through nursing actions, something they have not done before. Paula-for example, believes that she can express her pre-existing commitment to compassion when providing nursing care. Being compassionate is an integral part of her self identity and she cannot imagine being without being compassionate. Her compassion did not suddenly develop in nursing education, but she brings this already existing self to nursing; she offers her compassion to nursing. The only difference now is that she has different opportunities to express her compassion. Compassion is "the core of all the things that I do" and always being compassionate is integral to her self identity as Paula.

Engaging in nursing practice fits Kate's personal ontology too, because her experiences in nursing education are congruent with her experiences as a human being. She uses an image of Velcro to describe the close fit between her own self and nursing. Nursing, she says, "came and attached itself [to me]...like Velcro". Just as Velcro needs two complementary pieces that fit snugly together to create a strong bond, Kate believes that she bonds strongly with nursing. A conversation she had with a grade 8 teacher is a good example of her constructed, temporal understanding of self:

\section{I had this really amazing teacher in eighth grade, $\mathrm{Mr}$ Bowen, and I remember coming to him and saying, "I understand everything we're learning in this class, but I just can't seem to get these straight As, like all these other kids in the class, who I know don't understand it as well, but they get these amazing marks. And he said to me, "Oh, you know Kate, they're a bunch of sold-by-the-side- of-the-road long stemmed roses and you're a wild flower and you'll come into your own and when you do everything will make sense and you don't have to worry about all these other people." And he was so right! And I want to write him a letter now that I'm here and I feel that so deeply. Because I feel like in my evaluations from my clinical instructors and some of my professors and some of the things I read in my paper, I feel like they see me as I see me, maybe, and that has never happened before in university, or in glimpses. I think that's the biggest confirmation of why I'm supposed to be a nurse, want to be a nurse.}

By becoming a nurse, she has opened up like a flower to her true self. In fact, she feels obliged to become a nurse: "I'm supposed to be a nurse". Rather than this obligation being a burden, however, she understands it as being a positive development in her life. She is "able to express the elements of myself that are unique", which, until now, being in nursing education, have been muted.

Anne states that nursing is "better suited for my person". By judging what suits her as a person, she has a sense of self identity. Part of that identity is working with people, rather than working with inanimate objects. Recently, she had a job working with objects and felt too much stress because she needed to work with people. She did not become a people person until after entering nursing school and she assumes that she will always be a people person. Because nurses work closely with people, becoming a nurse is congruent with 
Anne's constructed self identity. Another participant, Lisa also needs an ontological fit between her work and her "real $m^{\prime \prime}$. She left a career in the sciences in order to "live a happy life" because she can now work with people. Her perspective reflects a temporal understanding of self because she compares her past unhappy life experiences with her current happy ones in nursing education.

Ricoeur uses the word character in his ontological theory, but researchers rarely, if ever, use that word in their research. I suggest that exploring character as a philosophical concept when engaging in research can help us understand the nursing student experience. Character comes from the Latin and means "to scratch, to engrave", 42 suggesting that someone's character is a relatively permanent mark of who that person is as a particular human being. Anne states that contemporary nursing education remains silent about students' character, but that educators should not ignore this important aspect of being human:

[University education] is all about consumerism. We pay money to get an education. You guys have a product. We buy that product. We are like a sausage factory, I think, because of money. We are, unfortunately. Things like character, or addressing character, that component we were talking about, it gets shuffled to the side because we need to learn how to do an injection or we need to do this... Maybe we will come back to that and realise that we can't ignore things like character.

Character has been important in nursing's past when-for example, educators admitted only students with good character. Rafferty writes about the politics of nursing knowledge and states that the first official nurses in the midVictorian era were "defined in terms of character rather than intellect. A good nurse could not be turned out from bad material". ${ }^{43}$ Nursing education was a "moral process, involving the development of character and self control rather than 'mere' academic training" (Rafferty, ${ }^{43}$ pp 26-7).

For all participants in this study, good nursing practice is more than competently applying a skill set, but includes being a certain type of person. Some described this more explicitly than others, but all agreed that exhibiting certain personal characteristics or being a certain kind of selfhaving a certain character-is essential for good nursing practice. As Anne states:

We know it's [nursing] not just tasks. It's so much more and it's really how we are as people. So we need to reflect. We need to examine ourselves and need to have other people challenge us in that capacity... It makes you a better person for sure.

Ricoeur uses character when describing the continuity of self that people experience over time, even as they inevitably change: "Character...designates the set of lasting dispositions by which a person is recognised" (Ricoeur, ${ }^{25} \mathrm{p} 121$ ). A person's action when exploring character is paramount because, as stated earlier, a person's dispositions or character are understood or made manifest by that person's actions. A person's habitual ways of acting distinguishes that person from another person. We talk about a person acting "out of character" when their actions surprise us. Dunne ${ }^{4}$ reflects the emphasis on action, too, when exploring character and states that while people can understand theory without action, they cannot understand character without action. Participants state that nursing was the "right fit" for them and I interpret this to reflect Ricoeur's understanding of character. Their nursing practice (or nursing action) reflects their own usual or habitual patterns of thinking and acting. Paula reflects the importance of appropriate character for nurses when she states that, after providing care for someone, she wants that person to walk "away not thinking about the care [they received]. They walk away thinking about the whole of me". She wants patients to remember who she is as a whole person-her character, her dispositionmore than remembering completed tasks.

For Anne, strong personal prefigurations (mimesis ${ }_{1}$ ) include a strict, Catholic upbringing and a father who insisted that she always be a "proper girl". In her family, one way to be proper was to respect others, especially those people who are in vulnerable situations. Because she just assumes respect is important in being human, she habitually (or characteristically) respects others. This prefiguration from Anne's childhood reflects what MacIntyre calls "standards of excellence $^{\prime \prime 45}$ that guide members of any community and become "scratched" or "engraved" on them. Individuals in a particular community measure their own actions against these standards, either explicitly or implicitly, as a way to distinguish themselves as a member of that community. Ricoeur refers to MacIntyre too, and states that people compare their own actions in relation to the "ideals of perfection shared by a given community of practitioners and internalised by the masters and virtuosi of the practice considered" (Ricoeur, ${ }^{25}$ p 176). For Anne, members of her community-for example, the Roman Catholic church, her family-respect vulnerable people and this expectation from her past shapes Anne's own character or her own habitual way of acting, a good example of the temporality of selfnarratives.

Participants talk about life experiences in their own character development. To develop good character, people need to practise good character through relevant experiences. Experience as a good teacher, however, is not just being exposed "to 'one damned thing after another' but rather of particulars giving rise to, and then being perceived in the light of, universals" (Dunne, ${ }^{44}$ p 59). Remembering past actions and their consequences helps a person consider specific actions in current and future situations. Considering these past specific actions and outcomes results in better judgments and actions the next time a person faces a similar situation. Interestingly, several participants wonder how younger students without many life experiences can provide appropriate care. Tracy (aged 26) states: "I would be scared of nursing at 18...I can't imagine being 18 in nursing at all". She now sees how important her life experiences are when she is making patient care decisions. Life experience helped build an important ontological foundation for her current nursing practice. She now has a firm footing that she perceives younger students do not have. When thinking about students just out of high school, she remembers what she was like at that age and cannot imagine that young students can provide appropriate nursing care. Tracy's incredulity can only occur with a temporal understanding of becoming a nurse. She remembers the kind of person she was eight years ago and states: "So, having eight years of life just teaches you a lot of things that you don't necessarily know where they come from, but they're there".

\section{TWO SUGGESTIONS: EXPLORING HEALTH/ILLNESS EXPERIENCES AND IMPLICATIONS FOR EDUCATORS}

I have two suggestions that incorporate the arguments I present in this paper. First, Ricoeur offers an appropriate framework methodologically and philosophically when studying any experience related to health and illness. Researchers-for example, could explore the experience of 
someone becoming a person with diabetes or becoming a person with chronic lung or heart disease. They could also study a person's ontological experience of cancer remission or gaining increased mobility after joint replacements. Research studies do exist that explore patient experiences with these diseases and illnesses, but few researchers have used an explicitly ontological framework as a guide for an empirical study.

My second suggestion relates to the education of health professionals. I assume that many readers of this article are, like me, involved in educating health professionals. In a recent editorial, Tanner ${ }^{46}$ wonders whether nurse educators should also explore students' selves (or their ontology), rather than assuming that an improved curriculum will automatically improve graduates. Rather than just wondering about an individual student's ontology, I think educators should explore that student's temporal understanding of their self identity. Doing so would help educators understand what motivates a particular student to a particular action. Since completing this project, I pay more attention to a particular student's prefigurations about their nursing practice and my own refigurations of that practice. By pressing students to articulate assumptions about their nursing actions, that is, by asking them to seriously consider their ontological motivation to act, I have had some success in helping students understand how their actions affect patient care. I take students to a psychiatric unit and two students' nursing practice improved when we worked together to articulate some negative prefigurations they had about patients with psychiatric conditions. By reflecting on their deeply held assumptions-that is, mimesis, both of them told me how much they had grown, not only as nursing students acquiring more knowledge, but also as human beings who will inevitably interact with mentally ill people outside of nursing. They had reconstructed their self identity, or who they were at an ontological level, and that resulted in more appropriate nursing actions. Through self reflection, they identified certain characteristics, or dispositions, that they wanted to change to become better nurses. They had come to nursing with some prefigurations that, upon reflection, limited their effectiveness and they were willing to change their self in order to improve their care for patients.

In conclusion, in any research project, the underlying methodological framework and any framework guiding analysis should be compatible. Because Ricoeur offers both a methodological perspective through mimesis and a framework for thinking about participants' experiences from a philosophical perspective, his thinking is especially appropriate for my own study, as well as for researchers exploring many phenomena that involve human beings.

Sources of support: 1. Social Sciences and Humanities Research Council (Canada), Doctoral Fellowship, Award no 752-2003-1637; 2. Faculty of Graduate Studies, University of Calgary, Calgary, Alberta, Canada

\section{REFERENCES}

1 Clayton GM, Broome ME, Ellis LA. Relationship between a preceptorship experience and role socialisation of graduate nurses. J Nurs Ed 1989;28:72-5

2 Colucciello ML. Socialisation into nursing: a developmental approach. Nursing Connections 1990;3:17-27.

3 Coudret NA, Fuchs PL, Roberts CS, et al. Role socialisation of graduating student nurses: impact of a nursing practicum on professional role conception. J Prof Nurs 1994;10:342-49.

4 Du Toit D. A sociological analysis of the extent and influence of professional socialisation on the development of a nursing identity among nursing students at two universities in Brisbane, Australia. J Adv Nurs 1995;21:164-71.

5 Itano JK, Warren JJ, Ishida DN. A comparison of role conceptions and role deprivation of baccalaureate students in nursing participating in a preceptorship or a traditional clinical program. J Nurs Ed 1987;26:69-73.

6 Nesler MS, Hanner MB, Melburg V, et al. Professional socialisation of baccalaureate nursing students: can students in distance nursing programs become socialized? J Nurs Ed 2001;40:293-302.
7 Diekelmann N. Behavioural pedagogy: a Heideggerian hermeneutical analysis of the lived experience of students and teachers in baccalaureate education. J Nurs Ed 1993;32:245-50.

8 Diekelmann N. Narrative pedagogy: Heideggerian hermeneutical analysis of lived experiences of students, teachers, and clinicians. Adv Nurs Sci $2001 ; 23: 53-71$

9 Kosowski JM. Clinical leaning experiences and professional nurse caring: a critical phenomenological study of female baccalaureate nursing students. J Nurs Ed 1995;34:235-42

10 Fagerberg I, Ekman S. Swedish nursing students' transition into nursing during education. Wes J Nurs Res 1998;20:602-20.

11 Gregg MF, Magilvy JK. Professional identity of Japanese nurses: bonding into nursing. Nurs Hlth Sci $2001 ; 3: 47-55$.

12 Holland K. A journey to becoming: the student nurse in transition. J Adv Nurs 1999;29:229-37.

13 Talseth A-G, Lindseth A, Jacobsson L, et al. The meaning of suicidal psychiatric inpatients' experiences of being cared for by mental health nurses. $J$ Adv Nurs 1999:29:1034-41.

14 Hellzen O, Asplund K, Sandman P-O, et al. Unwillingness to be violated: carers' experiences of caring for a person acting in a disturbing manner. An interview study. J Clin Nurs 1999;8:653-62.

15 Söderberg S, Lundman B, Norberg A. The meaning of fatigue and tiredness as narrated by women with fibromyalgia and healthy women. J Clin Nurs 2002; 11:247-55.

16 Sundin K, Axelsson K, Jansson L, et al. Suffering from care as expressed in the narratives of former patients in somatic wards. Scand J Car Sci 2000;14:16-22.

17 Svedlund M, Danielson E, Norberg A. Women's narratives during the acute phase of their myocardial infarction. J Adv Nurs 2001;35:197-205.

18 Nilsson I, Jansson L, Norberg A. To meet with a stroke: patients' experiences and aspects seen through a screen of crises. J Adv Nurs 1997;25:953-63.

19 Rasmussen BH, Sandman P-O, Norberg A. Stories of being a hospice nurse: a journey towards finding one's footing. Canc Nurs 1997:20:330-41.

20 Caap-Ahlgren M, Lannerheim L, Dehlin O. Older Swedish women's experiences of living with symptoms related to Parkinson's disease. J Adv Nurs 2002;39:87-95.

21 Fagerberg I, Kihlgren M. Experiencing a nurse identity: the meaning of identity to Swedish registered nurses two years after graduation. J Adv Nurs $2001 ; 34: 137-45$

22 Ricoeur P. Interpretation theory: discourse and the surplus of meaning. Fort Worth, TX: The Texas Christian University Press, 1976.

23 Ricoeur P. From text to action. Essays in hermeneutics II. Evanston, IL: Northwestern University Press, 1991

24 Ricoeur P. Time and narrative (vol 1). Chicago, IL: University of Chicago Press, 1984.

25 Ricoeur P. Oneself as another. Chicago, IL: University of Chicago Press, 1992.

26 Fredriksson L, Eriksson K. The ethics of caring conversation. Nurs Ethics 2003;10:138-48.

27 Valdés MJ. Introduction: Paul Ricoeur's poststructuralist hermeneutics. Ricoeur reader: reflection and imagination. Toronto, Ontario, Canada: University of Toronto Press, 1991:3-40.

28 Reagan CE. Paul Ricoeur: his life and his work. Chicago, IL: University of Chicago Press, 1996.

29 Pranger MB. Time and narrative in Augustine's Confessions. J Religion 2001;81:377-93

30 Gadamer H-J. Truth and method [2nd rev ed]. New York: Continuum, 1997.

31 Fisher L. Mediation, muthos, and the hermeneutic circle in Ricoeur's narrative theory. In: M Joy, ed. Paul Ricoeur and narrative. Calgary, Alberta, Canada: University of Calgary Press, 1997.

32 Brown T, Roberts L. Memories are made of this: temporality and practitioner research. Br Ed Res J 2000;26:649-59.

33 Ricoeur P. Hermeneutics and human sciences. Cambridge: Cambridge University Press, 1981

34 Britzman DP. Practice makes practice. New York: State University of New York Press, 1991.

35 Ricoeur $\mathbf{P}$. The human experience of time and narrative. In: Valdés MJ, ed. A Ricoeur reader: reflection and imagination. Toronto, Canada: University of Toronto Press, 1991:99-1 16

36 Ricoeur P. The hermeneutical function of distanciation. Phil Today 1973;17:129-41.

37 Tantillo $M$. Ricoeurean hermeneutics: its application in developing a contextual understanding of human experience. In: Chinn P, ed. Advances in methods of inquiry for nursing. Gaithersburg, MD: Aspen Press, 1994:103-20

38 Usher R. A critique of the neglected epistemological assumptions of educational research. In: Scott D, R Usher, eds. Understanding educational research. New York: Routledge, 1996:9-32.

39 Dunne J. Beyond sovereignty and deconstruction. In: Kearney R, ed. Paul Ricoeur: the hermeneutics of action. London: Sage, 1996:137-58.

40 Van den Hengel J. Paul Ricoeur's Oneself as Another and practical theology. Theol Stud 1994;55:458-80.

41 Fuss D. Essentially speaking. New York: Routledge, 1989

42 Woolfe HB, ed. Webster's new collegiate dictionary. Toronto, Ontario, Canada: Thomas Allen \& Son, 1976.

43 Rafferty AM. The politics of nursing knowledge. London: Routledge, 1996.

44 Dunne J. Back to the rough ground. Notre Dame, IN: University of Notre Dame Press, 1997.

45 Maclntyre A. After virtue, [2nd ed.]. Notre Dame, IN: University of Notre Dame Press, 1984.

46 Tanner $\mathrm{C}$. The meaning of curriculum: content to be covered or stories to be heard? J Nurs Ed 2004;43:3-4. 